\title{
New paradigm of social development in the context of digital economy
}

\author{
Yulia Ten $^{1 *}$ and Ivan Trifonov ${ }^{1}$ \\ ${ }^{1}$ Financial University under the Government of the Russian Federation, 125993, Moscow, Russia
}

\begin{abstract}
The relevance of the research is connected to the fact that in the context of the coming era of the industrial revolution 4.0, the globalization of the economy is the irreversible process that it involves more and more countries, regions and peoples. The authors guess that the digital economy is one of the consequences of the globalization of the world economy. The key idea consists in the suggestion that the digital economy constructs a basis for shaping new type of global human civilization. The goal of the study is the interdisciplinary analysis of the impacts of the digital economy on changing the paradigm of social development. One of the important results of the research is the thesis that the increasing the influence of the digital technologies on the social and economic life of people are changing model of thinking and behavior of contemporary peoples. The authors come to the conclusion that in the space of the digital economy the information and communication technologies contribute to break the traditional value system of society. The authors note that such values as information, mobility, speed, sociability, comfort, time saving, quality of services-begin to dominate the consciousness and behavior of a person in the context of digitalization of socio-economic life. It is revealed that these values are included in the field of the philosophical concept of pragmatism. These values are focused on obtaining mainly material benefits. The authors substantiate the need to develop the academic discussion about the risk of leveling traditional spiritual values, which for centuries were formed the meaning and value of human existence in society and nature.
\end{abstract}

\section{Introduction}

Globalization of the world economy is the inevitable process, which covers increasingly more and more countries all over the world. In core the digitalization is the expansion of the use of information and communication technologies that impact on all spheres of human life in society. Obviously, the progress in hardware and software development is inevitably moving humanity towards the formation of the "digital society" [1].

The author's hypothesis consists in the assumption that the policy of the states focused on stimulation of digitalization of national economies will lead to formation of the universal civilization. The subjects of such new type of civilization (both separate individuals and social groups, and the whole transnational corporations and interstate integration unions)

\footnotetext{
*Corresponding author: yulia ten10@mail.ru
} 
carry out exchange of messages (goods, services, information) by electronic means of the digital technologies. The trend towards digitalization of trade and economic, socio-cultural and political and legal life of the peoples has been leading to the global changes in the worldview of a modern person, his/her relations to other people, to nature and to technology. Today, globalization has created the inevitability of the formation of relationships between the economies of most countries of the world [2]. Each country opening the door to the space to the digital world, will inevitably be forced to necessary to accept the values, norms, patterns of thinking and behavior of the emerging digital civilization [3].

\section{Literature review}

The review of the contemporary academic literature on the issues of the research shows that the conceptual foundations of the study of the digital economy are in the stage of formation because of the novelty of this phenomenon. R. Bukh \& R. Heeks [4], C. Dahlmahn, S. Mealy, M. Wermelinger [5], R. Geissbauer, J. Vedso, S. Schrauf [6], R. Neeks [7], J.-S. Guy [8], S. Rappitsch [1], Richardson \& Bissell [2], K. Schwab [9] have contributed to more deeper understanding the origin and the formation of this phenomenon. The interdisciplinary approach to understanding the consequences of digital economies is presented in the works of M. Betancourt [10], M. Castels [3], T. Dufva \& M. Dufva [11], D. Tapscott [12].

The problem of digitalization of the economy is studied by Russian authors: I. V. Avdeev [13], V. V. Ivanov \& G. G. Malinetsky [144], V. G. Khalin \& G. V. Chernova [155] and others. However, the issue of changing the track of civilizational development of Russia under the influence of the adoption to the new system of norms, standards, patterns and values of the digital economy is practically not represented in the academic fields.

The goal of the study is the interdisciplinary analysis of the impact of the digital economy on changing the paradigm of social development.

\section{Research Method}

The authors develop the interdisciplinary approach to the study of the research topic, using concepts, approaches and methods from philosophy, sociology, economic theory and international economic relations. The complexity of the research issue is predetermined the appeal to the system method. The empirical basis of the study was constructed on the analysis of data from the web-sites of various organizations and companies.

\section{The changing of the attitudes to the value of human labor}

As is known from world historical practice, the impulses of economic development are revolutionary shifts in the exchange between society and nature through:

1) substances ("Neolithic "or "agrarian revolution»);

2) energy (revolution of the era of capitalism, held under the flag of the scientific and the experimental investigations and experiences of steam, electricity, internal combustion engines, the creation of nuclear power);

3) information (information revolution which its heart is the invention of computer's technology), forming the digital economy.

It is important to note that intangible production is key feature of digital capitalism. It is something other than a commodity form, namely "the influence of the aura of information" [10]. As M. Betancourt thinks, the spread of the "aura of information" is an attempt of 
digital capitalism to create a complete total description of all information as the universal tool, in which disparate measurements of all activities performed in the digital sphere become equally valuable for intangible production as a commodity [10, ii].

In the era of the industrial revolution 4.0 the emergence of increasingly complex machines driven by steam or electricity, performing calculations and other precise, highly specialized intellectual activities, are beginning to question about the meaning and the role of human labor in the contemporary industry. In the past centuries all productive functions often required the efforts of several hundred people and now they are become more independent [10, p. 24-25]. The emergence of new digital technologies has allowed machines to reduce human labor to a minimum or eliminate it completely. The production is continuing to develop without human control, guidance or interaction. Therefore, the automated production "dehumanizes the human labor" [10, p. 28].

For the deeper understanding of the revolutionary shift in the digital revolution of "Industry 4.0", the following philosophical conclusion of M. Betancourt is important. In the $\mathrm{XX}$ century, the transition from intangible values generated by automation of industry to material values generated by industry's automation indicates the fundamental shift in the nature of capitalist production. Human labor becomes less important for the automation of production [10, p. 31-32].

Thus, the emergence of production without the use of human labor, commodity and exchange values (both physical and intangible), has generated without the action of human will, can be seen as the key factors of shaping the basis of the digital revolution of the XXI century.

\section{Values of pragmatism are the basis of changes in the paradigm of social development}

The digitalization of the economy has become a "response" to the" challenge " of globalization in terms of discovering new means and technologies for more efficient and rapid interaction between different political and economic actors in the system of international division of labor.

It should be noted that the phenomenon of globalization originated in Europe in the XVII-XIX centuries [3, 16,17,]. The spread of globalization has been driven by different factors: the great geographical discoveries, the colonial expansion of various countries (including Russia, France, China, etc.), the powerful development of capitalist production and the formation of a new type of social relations, as well as the development of science and technologies.

One of the forms of theoretical analysis of the changes and shifts that occurred in Western society in the era of capitalism, was the philosophical trend of scientific knowledge, known as the philosophy of positivism (O. Comte, C. Pierce, G. Spencer), and neopositivism (R. Carnap, K. Popper, B. Russell, T. Kuhn, etc.).

If we interpret positivism as one of the" bricks " for the development of globalization, it can be considered as a general cultural and ideological installation of the consciousness of a Western society, which was formed in the course of asserting the dominance of the values of capitalism. The "spirit of positivism" brought radical changes to the hierarchy of values of a Western society. Historically, in the culture of feudal society, spiritual and moral values were considered as permanent religious and ethical norms and values [16]. In the self-consciousness of capitalist society has begun to appreciate the "earthly joy" of human being, his/her material and practical interests and productive and transformative activities in nature. Incrementally pragmatism has become as philosophy of life of the majority population of the Western countries. According to the views of one of the founding fathers of pragmatism, W. James, the truth of knowledge for man should be determined in terms of 
the usefulness of this knowledge for the success of human and social actions. James put forward the thesis that success is the only criterion for the truth of ideas. Moreover, it is success that forms the very content of the concept of truth [18].

According to J. Dewey, cognition is an instrument of adaptation of person to the environment and society. The measure of the truth of the theory is its practical expediency in a particular life situation. At the same time, practical expediency is the criterion not only of truth, but also of morality [18].

The trend to pragmatism in the model of Western thinking put into the development of the economy. At the dawn of the birth of a new type of technology (digital), Thomas Kuhn put forward the thesis that science should no longer be seen as a gradually accumulating system of knowledge about the world and man, aimed at the knowledge of truth. Science should be evaluated as a phenomenon going through certain stages "paradigm shift" [20]. The term "paradigm" (Greek. " $\pi \alpha \rho \alpha ́ \delta \varepsilon \gamma \gamma \mu \alpha ": ~ " p a t t e r n, ~ e x a m p l e, ~ s a m p l e ")$ implies the system of concepts and patterns of thought, including norms, postulates, standards, theories and research methods. The paradigm forms borders for admissible ways and approaches to the decision of any questions, formulation of hypotheses.

Hereby, the mankind of the XXI century has opening to door to the new era of power of digital technologies in economy and it has chosen a way of "shift of scientific paradigms" of social thinking and development. According to the results of experts of McKinsey Global Institute, in the next twenty years, up to $50 \%$ of work operations worldwide will be automated. In terms of its global scale, this process can be comparable to the industrial revolution of the XVIII-XIX centuries [20].

In the conditions of innovative economy "technologies, knowledge, innovations" were added to the traditional factors of production (labor, capital, raw materials, entrepreneurial activity) [15, p.36]. Thus, if in the pre-digital era the success of economic growth was achieved through the construction of large industrial and industrial complexes, the modern system of the world digital economy is constructed under the influence of innovations. Therefore, the contemporary application of digital computers for the collection, storage and processing of information requires consideration of a new theory of knowledge [10, 22, 23, 24].

Digitalization is current trend in the development of the economy and society, which is based on the transformation of information into digital form and it leads to the increase of the efficiency of the economy and improve the quality of life. Digitalization forms "technological environments (ecosystems, platforms) within which the user can create for himself the necessary friendly environment (technological, instrumental, methodical, documentary, partner, etc.) in order to solve entire cluster of problems" [15, p. 47].

\section{Conclusion}

The basis of the fourth industrial revolution is the digital economy, which is a new paradigm for the development of social and economic life of society, based on information and communication Internet technologies [9, p.16]. The digital technologies radically change the thinking of person, forming his/her view corresponding to environment and social reality of life in the digital world, as well as forming a new approach to the assessment of things, phenomena and processes. Following the concept of Karl Marx about the alienation of man in the era of industrial capitalism, we can conclude that man at the beginning of the XXI century so much alienate from the social and natural world that it turns into "homo ludens" (a term by Johan Huizinga). The "homo ludens" (Latin: "playing person") is completely detached from reality, he/she is so much immersed in the world of the virtual that he/she already becomes person of the new order, human being of digital civilization. 
Thus, the introduction of digital technologies contributes to changing the value system of the contemporary human society. Such values as information, mobility, speed, sociability, comfort, time saving, quality of services begin to dominate the consciousness and behavior of people. These values are consistent with the philosophical concept of pragmatism, as they are focused on obtaining mainly material benefits. The issue of leveling traditional spiritual values, which for many centuries formed the overview of human existence in society and nature, needs a deeper study. This ethic and philosophical problem should be the topic of further academic discussions.

\section{References}

1. C. Rappitsch, Digital economy and eustainability (OIKOS Associate Report, 2017). Information on https://oikos-international.org/wp-content/uploads/2015/06/oikosAssociate-Report-2017-Digital-Economy-and-Sustainability.pdf. Accessed 7 July 2019

2. L. Richardson, D. Bissell, Geographies of digital skil, Geoforum, 99 (2019)

3. M. Castells, The Internet Galaxy: reflections on the Internet, business and society (Oxford university press, Oxford, 2002)

4. R. Bukh, R. Heeks, Defining, conceptualising and measuring the Digital Economy, Global Development Institute working papers, 68, (2017). Information on https://diodeweb.files.wordpress.com/ 2017/08/diwkppr68-diode.pdf. Accessed 5 July 2019

5. . Dahlman, S. Mealy, M. Wermelinger, Harnessing the digital economy for developing countries (Publisher OECD, Paris, 2016)

6. R. Geissbauer, J. Vedso, S. Schrauf, Industry 4.0: building the digital enterprise 2016, Global Industry $4.0 \quad$ Survey. Information on https://www.pwc.com/gx/en/industries/industries-4.0/landing-page/industry-4.0building-your-digita-enterprise-april-2016.pdf. Accessed 7 June 2019

7. R. Heeks, Information and communication technology for development (Routledge, Abingdon, 2017)

8. J.-S. Guy, Digital technology, digital culture and the digital metric/nonmetric distinction, Technological forecasting and social change, 145 (2019)

9. K. Schwab, The fourth industrial revolution (Penguin, L., 2017)

10. M. Betancourt, The critique of digital capitalism: an analysis of the political economy of digital culture and technology (Punctum books, N.-Y., 2015)

11. T. Dufva \& M. Dufva, Grasping the future of the digital society, Futures, 107 (2019).

12. D. Tapscott, The digital economy: promise and peril in the age of networked intelligence (McGrawHill, N.-Y., 1996)

13. I.V. Avdeev, Strukturno-cifrovaya transformaciya kak faktor innovacionnogo razvitiya regional'noj ekonomicheskoj sistemy (Diss. kand. ekonom. nauk. Voronezh, 2019)

14. V.V. Ivanov, G.G. Malineckij, Cifrovaya ekonomika: mify, real'nost', vozmozhnosti (Rossijskaya akademiya nauk, M., 2017)

15. V.G. Khalin, G.V. Chernova, Digitalization and Its Impact on the Russian economy and society: advantages, challenges, threats and risks, Management consulting, 10 (2018)

16. F. Braudel, A history of civilizations (Penguin Books, N.-Y., 1993)

17. A. Giddens, Capitalism and modern social theory (Cambridge university press, Cambridge, 1990) 
18. W. James, Pragmatism (L., 1907)

19. J. Dewey, The Public and its Problems (Denver, 1927)

20. T. Kuhn, The structure of scientific revolutions (University of Chicago press, Chicago, 1970)

21. A. Aptekman i dr., Cifrovaya Rossiya novaya realnost (Digital McKinsey). Information on http://www.tadviser.ru/images/c/c2/Digital-Russia-report.pdf. Accessed 5 June 2019

22. F. Agostinone-Wilson, A critical overview of the digital knowledge commons from a Marxist perspectives, Knowledge cultures, 4(6), (2016)

23. W.D. Holford, The future of human creative knowledge work within the digital economy. (Futures, 105, 2019)

24. S. Roth, Digital transformation of social theory. A research update, Technological forecasting and social change, 146, (2019) 